\title{
PENGARUH TATA KELOLA PEMERINTAH DAERAH TERHADAPTRANSPARANSI PENGELOLAAN KEUANGAN DAERAH: BUKTI EMPIRIS PADA PEMERINTAH PROVINSI DI INDONESIA
}

\author{
Syamsul dan Irwan Taufiq Ritonga \\ Magister Sains dan Doktor UGM dan Fakultas Ekonomika dan Bisnis UGM \\ Email:abangupi@yahoo.com
}

\begin{abstract}
This study developed a research Beekes and Brown (2006) who found that corporate governance makes companies more informative (more transparent). This study aims to prove whether the same results were also found in environmental governance in Indonesia. The theory is used to achieve the goal of this research is the theory of agency. This research was conducted in 32 local governments in Indonesia. Based on a simple regression model, this study shows that local governance affects positively the transparency of local financial management. Such findings reinforce previous research. The findings of this study provide a useful contribution to government officials (executive and legislative), in demonstrating the important role of local governance in encouraging the transparency of local financial management. In addition, the findings of this study can be used as the basis for further research related to the topic of local governance and transparency of local financial management.
\end{abstract}

Keywords: Transparency of Local Financial Management, Governance

\begin{abstract}
Abstrak: Penelitian ini mengembangkan penelitian Beekes dan Brown (2006) yang menemukan bahwa tata kelola perusahaan menjadikan perusahaan lebih informatif (lebih transparan). Penelitian ini bertujuan untuk membuktikan apakah hasil yang sama juga ditemukan dalam lingkungan pemerintahan di Indonesia.Teori yang digunakan untuk mencapai tujuan penelitian ini adalah teori agensi. Penelitian ini dilakukan pada 32 pemerintah daerah di Indonesia. Berdasarkan model regresi sederhana, penelitian ini menunjukkan bahwa tata kelola pemerintah daerah berpengaruh secara positif terhadap transparansi pengelolaan keuangan daerah. Temuan tersebut menguatkan penelitian sebelumnya. Temuan penelitian ini memberikan kontribusi yang bermanfaat bagi pejabat pemerintahan (eksekutif dan legislatif), dalam menunjukkan peran penting tata kelola pemerintah daerah dalam mendorong transparansi pengelolaan keuangan daerah. Selain itu, temuan penelitian ini dapat dijadikan pijakan untuk penelitian selanjutnya yang terkait dengan topik tata kelola pemerintah daerah dan transparansi pengelolaan keuangan daerah.
\end{abstract}

\section{PENDAHULUAN}

Reformasi Keuangan daerah di Indonesia ditandai dengan diterbitkannya paket undang-undang (UU) Keuangan Negara (UU No. 17 Tahun 2003, UU No. 1 Tahun 2004, dan UU No. 15 Tahun 2004) dan UU tentang Otonomi Daerah (UU No. 32 Tahun 2004 dan UU No. 33 Tahun 2004), serta Peraturan Pemerintah (PP) (PP No. 58 Tahun 2005) dan diikuti dengan Peraturan Menteri Dalam Negeri (Permendagri) (Permendagri No. 13 Tahun 2006). Salah satu sorotan utama reformasi keuangan daerah adalah terwujudnya pengelolaan keuangan publik yang transparan dengan berlandaskan pada konsep value for 
money sehingga tercipta akuntabilitas publik (public accountability) (Mardiasmo, 2009:20).

Transparansi pengelolaan keuangan daerah dipertegas dengan diterbitkannya UU No. 14 Tahun 2008 tentang Keterbukaan Informasi Publik yang menyatakan bahwa setiap badan publik, termasuk pemerintah daerah, berkewajiban menerbitkan informasi publik atas setiap aktivitas yang dilaksanakannya. UU ini, kemudian ditindaklanjuti dengan diterbitkannya Instruksi Menteri Dalam Negeri (Mendagri) No. 188.52/1797/SJ/2012 tentang Peningkatan Transparansi Pengelolaan Anggaran Daerah (TPAD). Instruksi Mendagri tersebut mengamanatkan pemerintah daerah untuk menyiapkan menu content dengan nama TPAD dalam website resmi pemerintah daerah.

Namun demikian, beberapa temuan penelitian yang menunjukkan bahwa peraturanperaturan yang diterbitkan tersebut ternyata tidak serta merta diiringi dengan peningkatan transparansi pengelolaan keuangan daerah itu sendiri. Hal ini dapat dilihat dari temuan penelitian terdahulu (lihat, Hermana et al., 2012; Sofia dan Husen, 2013; Seknas Fitra, 2013; dan Martani et al., 2014) yang menginformasikan bahwa tingkat transparansi pengelolaan keuangan daerah masih sangat rendah. Selanjutnya, fenomena rendahnya transparansi pengelolaan keuangan daerah juga tercermin dari masih maraknya kasus korupsi yang melibatkan pejabat politik daerah. Kementrian Dalam Negeri (Kemendagri) mencatat bahwa sebanyak 361 kasus korupsi melibatkan kepala daerah selama periode tahun 2010 hingga Agustus 2016 (Tirto.id, 29 September2016), sementara Indonesian Corruption Watch (ICW) melaporkan bahwa sebanyak 183 kepala daerah menjadi tersangka kasus korupsi dalam kurun waktu tahun 2010 hingga 2015 (Antikorupsi.org, 28 Agustus2016).

Selanjutnya, beberapa penelitian terdahulu (lihat, Beekes dan Brown, 2006; dikembangkan, Aman et al., 2011; Beekes et al., 2014; 2016a; 2016b) telah menunjukkan bahwa kebijakan transparansi bergantung pada dan dipengaruhi oleh kualitas tata kelola. Namun, penelitian tersebut masih terbatas dilakukan pada sektor privat (perusahaan). Sebaik pengetahuan peneliti, belum ada penelitian empiris yang secara spesifik meneliti apakah tata kelola pemerintah daerah memiliki pengaruh terhadap transparansi pengelolaan keuangan daerah di Indonesia. Oleh karena itu, peneliti termotivasi untuk mengembangkan penelitian dari Beekes dan Brown (2006) ke dalam konteks pemerintah dengan menganalisis pengaruh tata kelola pemerintah daerah terhadap transparansi pengelolaan keuangan daerah. Menariknya, meski tata kelola pemerintah daerah itu diadopsi dari tata kelola perusahaan dengan tujuan yang sama, yaitu untuk meningkatkan kinerja dan kepercayaan pemangku kepentingan. Akan tetapi, secara struktur dan implementasi strategi, tata kelola pemerintah lebih kompleks (multi-layered) dibandingkan dengan tata kelola perusahaan (Spanhove dan Verhoest, 2007). Dengan demikian apakah hasil yang sama, yang ditemukan dalam lingkungan perusahaan juga ditemukan dalam lingkungan pemerintahan, hal ini masih menyisakan pertanyaan.

Sayangnya, belum ada bukti empiris tentang pentingnya tata kelola pemerintah daerah dalam mewujudkan transparansi pengelolaan keuangan daerah. Padahal, informasi tersebut bermanfaat bagi para pejabat pemerintahan (eksekutif dan legislatif). Dalam hal pengambilan keputusan yang efektif terkait dengan upaya-upaya peningkatan transparansi pengelolaan keuangan daerah di masa mendatang. Penelitian ini berusaha memberikan kontribusi pada pengembangan literatur akuntansi publik dengan menginvestigasi pengaruh tata kelola pemerintah daerah terhadap transparansi pengelolaan keuangan 
daerah. Penelitian ini dibagi menjadi lima bagian utama, yakni pendahuluan, tinjauan pustaka, metode penelitian, hasil dan pembahasan, dan simpulan dan saran.

\section{KAJIAN TEORI}

Humayun dan Ismail (2012) menyatakan bahwa teori keagenan sebagai teori utama yang digunakan dalam pembahasan tata kelola perusahaan. Secara khusus, teori keagenan diarahkan pada hubungan keagenan, dimana satu pihak (prinsipal) mendelegasikan pekerjaan kepada pihak lain (agen) yang melakukan pekerjaan tersebut. Konflik kepentingan antara pemilik dan agen terjadi karena kemungkinan agen tidak selalu berbuat sesuai dengan kepentingan prinsipal (Jensen dan Meckling, 1976). Ringkasnya, teori keagenan muncul karena setiap individu diasumsikan akan mempunyai preferensi untuk memaksimalkan utilitas pribadi, yang kemungkinan besar berlawanan dengan kepentingan individu lain. Sebagai agen, di satu sisi manajer secara moral memiliki tanggung jawab untuk mengoptimalkan keuntungan prinsipal (pemilik), namun di sisi lain manajer juga mempunyai kepentingan untuk memaksimalkan kesejahteraan mereka. Hal tersebut menyebabkan agen tidak selalu bertindak demi kepentingan terbaik prinsipal dan melakukan kecurangan.

Kecurangan yang dilakukan manajer (agen) dapat merugikan pihak pemilik (prinsipal). Salah satu bentuk kecurangan yang dapat dilakukan manajer adalah kecenderungan untuk menyembunyikan informasi perusahaan (keuangan dan nonkeuangan). Kondisi ini dikenal dengan istilah informasi yang tidak seimbang (asimetri informasi). Asimetri informasi antara manajer dan pemilik, dapat memberikan ruang bagi agen untuk berperilaku oportunis, yaitu memperoleh keuntungan pribadi. Menurut Beekes et al. (2016a) bahwa prinsipal dapat membatasi perilaku tersebut dengan menyediakan insentif bagi manajer (misalnya, opsi saham) dan menimbulkan biaya monitoring (seperti pemeriksaan periodik laporan keuangan perusahaan oleh auditor eksternal). Di sisi lain agen juga dapat dikenakan beberapa biaya penjaminan (bonding cost) untuk meyakinkan prinsipal atas niat baik mereka.

Hak-hak masing-masing pihak dalam hubungan keagenan dapat ditentukan dalam kontrak diantara mereka (Beekes et al., 2016a). Menurut Hart (1995) kontrak dalam hubungan agensi tidak lengkap dalam arti bahwa hal itu tidak dapat mencakup semua kontinjensi di masa depan, dan penegakan kontrak juga mahal. Oleh karena itu, struktur dan proses tata kelola perusahaan dapat memainkan peran yang berguna dalam menyelesaikan konflik keagenan (Beekes et al., 2016b). Organisation for Economic Cooperation and Development (OECD) (2004: 11) seperti yang dikutip Beekes et al. (2016b) menjelaskan bahwa konsep tata kelola perusahaan adalah "seperangkat hubungan antara manajemen perusahaan, dewan, pemegang saham dan pemangku kepentingan lainnya. Tata kelola perusahaan menyediakan struktur melalui penetapan tujuan perusahaan dan cara mencapai tujuan tersebut dan pemantauan kinerja perusahaan". Contohnya, dewan direksi (komisaris) dapat berperan dalam "memonitor (mengawasi) dan meratifikasi (mengesahkan) keputusan penting" dari manajer (Beekes et al., 2016a). Dengan demikian, konsep tata kelola perusahaan yang baik dianggap dapat menyelaraskan kepentingan terbaik pemegang saham dan manajer (Beekes et al., 2016b) dan menguragi asimetri informasi dengan biaya secara teoritis diasumsikan kurang dari manfaat yang didapatkan (Tsamenyi et al., 2007). Singkatnya, tata kelola perusahaan disebut pula sebagai suatu sistem yang mengarahkan dan pengawasan terhadap aktivitas perusahaan. Konsep tata 
kelola perusahaan merupakan suatu mekanisme yang dapat digunakan oleh pemegang saham dan pemangku kepentingan lainnya, untuk mengontrol tindakan manajer (agen).

Sebelumnya, Beekes dan Brown (2006) mengungkapkan bahwa struktur tata kelola perusahaan dapat memengaruhi praktik pengungkapan dan memastikan perusahaan mengikuti "kebijakan optimal" keterbukaan informasi kepada pelaku pasar (Shleifer dan Vishny, 1997; Core, 2001). Menurut Beekes et al. (2016a) tata kelola perusahaan yang lebih baik mengungkapkan informasi lebih banyak kepada pihak eksternal dan lebih transparan, karena pengawasan yang lebih ketat. Demikian pula Hermalin dan Weisbach (2012) juga menjelaskan bahwa bagaimana perusahaan dikelola dan diawasi memengaruhi tingkat transparansi dan pengungkapan informasi perusahaan. Dari argumentasi tersebut, dapat pula dikatakan bahwa kualitas tata kelola perusahaan menjadikan transparansi perusahaan yang lebih luas.

Dalam konteks pemerintah daerah, Mardiasmo (2004) menjelaskan bahwa secara umum mekanisme tata kelola pemerintah daerah dibentuk tiga domain utama yaitu pemerintah (eksekutif), DPRD/legislatif (shareholders) dan masyarakat (stakeholders). Fungsi pengawasan yang dilakukan oleh legislatif dan partisipasi masyarakat secara langsung maupun tidak langsung melalui LSM dan organisasi sosial kemasyarakatan di daerah (social control) menjadi kekuatan penyeimbang (balance of power) bagi eksekutif daerah. Selain itu, pengawasan dan pengendalian dimaksudkan untuk memastikan penyelenggaraan pemerintahan tetap berjalan berdasarkan prinsip-prinsip dan peraturanperaturan yang telah ditetapkan. Pengawasan yang ketat dan partisipasi masyarakat yang tinggi (tercermin dari kualitas tata kelola pemerintah) menyebabkan perilaku oportunis pemerintah daerah dan kecenderungan menutupi informasi dapat direduksi, sehingga mengurangi asimetri informasi dan akhirnya mengarah pada peningkatan transparansi pengelolaan keuangan daerah.

Penelitian empiris tentang pengaruh tata kelola terhadap transparansi dipelopori oleh Beekes dan Brown (2006) pada konteks privat (perusahaan). Mereka mengajukan pertanyaan penelitian "Do better-governed australian firms make more informative disclosures?" Sampel penelitian terdiri dari 250 perusahaan Australia yang terdaftar di dalam Horwath Corporate Governance Report 2002. Hasil regresi membuktikan bahwa tata kelola perusahaan berpengaruh positif dengan frekuensi dan ketepatan waktu pengungkapan. Ringkasnya, penelitian ini menunjukkan bahwa tata kelola perusahaan yang baik membuat pengungkapan lebih informatif. Penelitian ini juga merekomendasikan untuk dilakukan penelitian lanjutan di negara yang berbeda dan dengan jangka waktu yang lebih panjang.

Temuan penelitian Beekes dan Brown (2006) tersebut, kemudian dikembangkan oleh Aman et al. (2011) di Jepang. Mereka menguji pengaruh tata kelola perusahaan terhadap transparansi perusahaan. Secara keseluruhan penelitian ini menunjukkan bahwa tata kelola perusahaan yang baik menjadikan pengungkapan yang lebih sering. Beekes et al. (2014) menguji hubungan antara tata kelola perusahaan dan pengungkapan dengan menggunakan data Australia time series periode (2001-2008). Hasil regresi menunjukkan bahwa sejak ASX Corporate Governance Guidelines diperkenalkan pada tahun 2003, secara umum perusahaan menunjukkan peningkatan frekuensi pengungkapan dan ketepatan waktu berita buruk relatif terhadap berita baik, pemerataan praktik pengungkapan dan transparansi yang lebih luas. 
Selanjutnya, Beekes et al. (2016a) menguji pengaruh tata kelola perusahaan terhadap praktik pengungkapan dan transparansi perusahaan. Penelitian ini dilakukan terhadap 5.000 perusahaan yang terdaftar di 23 negara. Hasil regresi kembali mengkonfirmasi bahwa tata kelola perusahaan yang lebih baik membuat frekuensi pengungkapan lebih sering (lebih transparan). Demikian pula, penelitian Beekes et al. (2016b) yang dilakukan di Kanada, juga berhasil membuktikan bahwa komponen tata kelola perusahaan berhubungan dengan pengungkapan dan transparansi perusahaan. Berdasarkan penjelasan di atas, penelitian ini merumuskan hipotesis berikut (dinyatakan dalam bentuk alternatif) mengenai pengaruh tata kelola pemerintah daerah terhadap transparansi pengelolaan keuangan daerah.

Ha: Terdapat pengaruh tata kelola pemerintah daerah terhadap transparansi pengelolaan keuangan daerah

\section{METODE}

Data penelitian ini berupa nilai kinerja tata kelola daerah dan data pengelolaan keuangan daerah. Data indeks tata kelola daerah pemerintah daerah diperoleh dari Indonesia Governance Index 2012. Data pengelolaan keuangan daerah diolah dari masingmasing website resmi pemerintah daerah. Sampel penelitian ini adalah terdiri dari 32 (tiga puluh dua) pemerintah daerah di Indonesia. Teknik pengambilan sampel penelitian secara non probabilitas (pemilihan non-random) dengan metode purposive sampling. Pengambilan sampel dengan metode tersebut didasarkan pada jumlah data yang tersedia, khususnya nilai tata kelola pemerintah daerah masih terbatas pada beberapa pemerintah daerah saja. Dengan demikian tidak dimungkinkan untuk dilakukan dengan sistem random (acak), karena tidak semua pemerintah daerah mendapatkan nilai tata kelola. Adapun kriteria-kriteria digunakan untuk menyaring sampel adalah sebagai berikut. (1) Pemerintah daerah yang memperoleh nilai indeks tata kelola daerah yang dikeluarkan oleh Indonesia Governance Index Tahun 2012; (2) Pemerintah daerah yang tidak memiliki website resmi dan atau tidak dapat diakses dikeluarkan dari sampel. Tabel I berikut ini menunjukkan proses pemilihan sampel berdasarkan kriteria-kriteria yang telah ditentukan di atas.

Tabel 1. Prosedur Pemilihan Sampel

\begin{tabular}{ll}
\hline Kriteria: & Jumlah \\
\hline 1. Pemerintah daerah yang memperoleh nilai indeks tata kelola & 33 \\
daerah yang dikeluarkan oleh Indonesia Governance Index & \\
$\quad \begin{array}{l}\text { Tahun 2012 } \\
\text { 2. Dikeluarkan karena tidak memiliki website resmi dan atau } \\
\text { tidak dapat di akses }\end{array}$ & 1 \\
Sampel Akhir & 32 \\
\hline
\end{tabular}

Penelitian ini menggunakan jeda waktu dalam menguji pengaruh tata kelola pemerintah daerah terhadap transparansi pengelolaan keuangan daerah. Hal ini sesuai dengan penelitian Beekes dan Brown (2006) di Australia dalam konteks tata kelola perusahaan. Mereka memprediksi keinformatifan informasi yang disajikan perusahaan tahun $\mathrm{t}$ (sekarang) berdasarkan pada kualitas tata kelola perusahaan tahun $\mathrm{t}-1$ (sebelumnya). Mengingat, struktur dan kompleksitas organisasi pemerintah, sehingga peneliti menganggap dampak dari tata kelola pemerintah memiliki jeda waktu yang lebih 
panjang dibandingkan dengan tata kelola perusahaan. Dalam penelitian ini, peneliti menggunakan jeda waktu 3 (tiga tahun).

Dalam penelitian ini tata pemerintah daerah didefinisikan sebagai proses memformulasi dan melaksanakan kebijakan, peraturan serta prioritas-prioritas pembangunan melalui interaksi antara eksekutif, legislatif, dan birokrasi dengan partisipasi dari masyarakat sipil dan masyarakat ekonomi (bisnis). IGI merupakan alat untuk mengukur kinerja pemerintahan daerah, khususnya terhadap empat arena yaitu arena pemerintah (eksekutif dan legislatif), birokrasi, masyarakat sipil, dan masyarakat ekonomi berdasarkan beberapa kriteria data yang obyektif dan terukur. Dengan menggunakan skala pengukuran dari angka 1 (terendah) hingga 10 (tertinggi). Nilai yang dikeluarkan oleh IGI 2012 dinyatakan dalam satuan desimal.

Sementara itu, transparansi pengelolaan keuangan daerah didefinisikan sebagai suatu bentuk keterbukaan pemerintah dalam membuat kebijakan-kebijakan pengelolaan keuangan, sehingga dapat diketahui dan diawasi oleh publik (masyarakat), mulai dari proses perencanaan, pelaksanaan, penatausahaan, pelaporan, pertanggungjawaban, dan pengawasan. Pengukuran transparansi pengelolaan keuangan daerah didasarkan pada tiga tahapan utama pengelolaan keuangan daerah, yaitu (1) perencanaan; (2) pelaksanaan; dan (3) pelaporan dan pertanggungjawaban pelaksanaan APBD.

Lebih lanjut, masing-masing tahapan diukur dengan menggunakan 3 (tiga) kriteria utama transparansi informasi pengelolaan keuangan daerah, yaitu: ketersediaan, aksesibilitas, dan ketepatan waktu pengungkapan. Ketersediaan menunjukkan bahwa informasi pengelolaan keuangan daerah yang diukur tersedia di website resmi pemerintah daerah. Aksesibilitas menunjukkan bahwa informasi yang tersedia tersebut dapat diunduh oleh publik. Sementara itu, ketepatan waktu pengungkapan didefinisikan sebagai informasi mengenai pengelolaan keuangan daerah disajikan (disediakan) di website resmi pemerintah daerah, sesuai dengan rentang waktu yang dipersyaratkan (diharapkan). Lebih lanjut, ketepatan waktu dinilai berdasarkan tanggal unggah pemerintah daerah dalam mengungkapkan informasi pengelolaan keuangan daerah dengan membandingkan tanggal yang dipersyaratkan (diharapkan) peneliti. Dalam penelitian ini waktu yang dipersyaratkan adalah 30 (tiga puluh) hari setelah dokumen pengelolaan keuangan daerah ditetapkan. Pengambilan keputusannya adalah apabila pemerintah daerah mempublikasikan informasi pengelolaan keuangan daerah pada rentang waktu yang dipersyaratkan, maka dinyatakan tepat waktu. Sebaliknya, apabila informasi pengelolaan keuangan daerah dipublikasikan melewati rentang waktu yang dipersyaratkan, maka dinyatakan tidak tepat waktu.

Instrumen transparansi pengelolaan keuangan daerah dimodifikasi dari instrumen penelitian Huwae (2016). Modifikasi instrumen Huwae (2016) dengan menambahkan indikator aksesibilitas, ketepatan waktu publikasi, dan perubahan tanggal dan tahun pengamatan pengelolaan keuangan daerah. Penilaian pada tahap perencanaan APBD terdiri dari 10 (sepuluh) indikator, tahap pelaksanaan APBD terdiri dari 9 (sembilan) indikator, dan tahap pelaporan dan pertanggungjawaban APBD terdiri dari 10 (sepuluh) indikator. Untuk lebih jelasnya mengenai ringkasan poin-poin instrumen pengukuran transparansi pengelolaan keuangan daerah dapat dilihat pada lampiran I penelitian ini.

Selanjutnya, pengambilan data dilakukan dengan menelusuri website resmi pemerintah daerah selama bulan November 2016 sampai dengan awal bulan Januari 2017. Adapun cara penentuan indeks transparansi adalah; Pertama, pengukuran menggunakan skor dikotomi, Jika suatu item tersedia, dapat diakses, dan tepat waktu diberi nilai 
masing-masing 1 untuk setiap kriteria dan jika tidak tersedia, tidak dapat diakses (diunduh), dan tidak tepat waktu akan diberi nilai 0. Kedua, skor yang diperoleh untuk kriteria ketersediaan dan aksesibilitas masing-masing dikalikan 0,25, dan ketepatan waktu dikalikan 0,5, kemudian dijumlahkan untuk mendapatkan skor total untuk setiap indikator (item). Ketiga, skor yang diperoleh setiap indikator dijumlahkan untuk mendapatkan skor total untuk setiap pemerintah daerah. Keempat, menghitung tingkat transparansi dengan cara membagi total skor yang diperoleh dengan total skor yang diharapkan dapat diperoleh oleh setiap indikator, kemudian dikalikan seratus.

\section{HASIL DAN PEMBAHASAN}

Hasil Statistik Deskriptif dan Uji Asumsi Klasik. Berdasarkan pada hasil statistik deskriptif diketahui bahwa variabel tata kelola pemerintah daerah memiliki nilai minimum 4,45 dari indeks terendah sebesar 0,00, nilai maksimum 6,80 dari indeks tertinggi sebesar 10,00, dan nilai rata-rata sebesar 5,74. Variabel transparansi pengelolaan keuangan daerah memiliki nilai minimum 3.45 dari indeks terendah sebesar 0,00, nilai maksimum 50,00 dari indeks tertinggi sebesar 100,00, dan nilai rata-rata sebesar 17,24.

Selanjutnya, dilakukan uji asumsi klasikyang bertujuan untuk memastikan apakah model regresi dalam penelitian ini dengan metode estimasi Ordinary Least Square (OLS) memberikan hasil yang Best Linear Unbiased Estimator (BLUE) atau tidak. Secara umum uji asumsi klasik pada model regresi adalah uji normalitas, heterokedastisitas, multikolonieritas, dan autokorelasi. Menurut Ghozali (2011:103) uji multikolonieritas bertujuan untuk menguji apakah model regresi ditemukan adanya korelasi antar variabel bebas (independen). Uji autokorelasi bertujuan menguji apakah dalam model regresi linear ada korelasi antara kesalahan penganggu pada periode $t$ dengan kesalahan pada periode $t-1$ (sebelumnya). Uji heteroskedastisitas dilakukan untuk menguji apakah dalam sebuah model regresi terjadi ketidaksamaan variance dari residual dari satu pengamatan ke pengamatan yang lain. Selanjutnya, uji normalitas bertujuan untuk menguji apakah dalam model regresi, variabel pengganggu atau residual memiliki distribusi normal. Dengan demikian, model regresi penelitian ini hanya menggunakan uji normalitas dan uji heteroskedastisitas. Hal ini dikarenakan, penelitian ini hanya memiliki satu variabel independen sehingga tidak memenuhi asumsi pengujian multikolonieritas. Demikian pula data yang digunakan hanya satu periode pengamatan sehingga tidak memenuhi asumsi pengujian autokorelasi.

Uji normalitas data dilakukan dengan dengan analisis grafik dan uji statistik (Ghozali, 2011:160). Dari analisis dilihat bahwa data menyebar disekitar garis diagonal dan mengikuti arah garis diagonalnya (lihat, lampiran II), sehingga dapat disimpulkan bahwa model regresi memenuhi asumsi normalitas. Sementara itu, analisis statistik dengan uji Kolmogorov-Smirnov (K-S), menunjukkan besarnya nilai K-S adalah 0,453 dan nilai signifikansi yang diperoleh sebesar 0,986 . Hal ini berarti residual dalam model regresi berdistribusi normal karena nilai signifikansi lebih besar dari nilai signifikansi yang ditetapkan yaitu $0,05(0,986>0,05)$. Dari pengujian tersebut, dapat dinyatakan bahwa residual dalam model regresi penelitian ini berdistribusi normal. Lebih jelasnya dapat dilihat pada Lampiran II penelitian ini.

Sementara itu, pengujian untuk membuktikan terjadi atau tidak terjadi heteroskedastisitas dalam penelitian dilakukan dengan analisis grafik dan analisis statistik 
(Ghozali, 2011:139). Selain itu, dilakukan juga uji tambahan dengan menggunakan pengujian Spearman's Rank Correlation. Dari analisis grafik scatterplot, terlihat bahwa titik-titik menyebar secara acak serta tersebar baik di atas maupun di bawah angka 0 pada sumbu Y (lihat, Lampiran II). Hal ini berarti tidak terjadi heteroskedastisitas pada model regresi. Begitu pula, analisis statistik dengan menggunakan uji Glejser, dapat dilihat bahwa variabel independen, yakni tata kelola pemerintah daerah (LnTKPD) tidak signifikan secara statistik mempengaruhi variabel dependen, yaitu Absolut Unres. Dengan nilai $p$-value sebesar 0,991 di atas nilai signifikansi yang ditetapkan sebesar 0,05 (0,991 > 0,05), sehingga dapat dikatakan bahwa model regresi bebas dari masalah heteroskedastisitas. Selanjutnya, pengujian dengan menggunakan Spearman's Rank Correlation juga menunjukkan korelasi antara tata kelola pemerintah daerah (LnTKPD), transparansi pengelolaan keuangan daerah (LnTPKD) dengan nilai absolut (AbsUnres) lebih besar dari $5 \%(0,918$ dan 0,950 > 0,05). Hal ini berarti konsisten dengan pengujian sebelumnya, dengan demikian dapat disimpulkan bahwa model regresi bebas dari masalah heteroskedastisitas. Lebih lanjut, dapat dilihat pada Lampiran II penelitian ini.

Hasil Analisis Regresi Sederhana. Analisis regresi sederhana digunakan untuk menguji dan memberikan bukti empiris mengenai pengaruh tata kelola pemerintah daerah terhadap transparansi pengelolaan keuangan daerah. Analisis regresi menggunakan software SPPS IBM 21.

Model regresi dalam penelitian ini dirumuskan dalam persamaan sebagai berikut:

$$
\operatorname{LnTPKD}=\mathrm{a}+\mathrm{b} \operatorname{LnTKPD}+\mathrm{e}
$$

Keterangan: LnTKPD = Log natural Tata Kelola Pemerintah Daerah 2012; LnTPKD = Log natural Transparansi Pengelolaan Keuangan Daerah 2016; $a=$ Konstanta; $b=$ Koefisien regresi; e = Kesalahan Penggangu (Error term).

Model di atas, diadaptasi dari Beekes dan Brown (2006), Arman et al. (2012), serta Beekes et al. (2014; 2016a; 2016b) dalam kontek perusahaan. Namun demikian, tidak semua variabel independen (kontrol) dari penelitian tersebut dimasukkan dalam model penelitian ini, seperti ukuran (size), solvabilitas (leverage), berita baik (good news), dan votalitas (volatility). Hal ini dikarenakan, kompleksitas organisasi pemerintahan dan perbedaan tujuan organisasi. Dengan kata lain, lingkungan pemerintahan berbeda signifikan dengan lingkungan perusahaan. Akibatnya, pengukuran variabel tersebut juga akan berbeda ketika diterapkan dalam lingkungan pemerintahan, sehingga memerlukan penelitian lain untuk membahas masalah tersebut. Oleh karena itu, penelitian ini hanya berfokus pada satu variabel prediktor (tata kelola) saja, sebagai penelitian pertama dalam konteks pemerintah daerah di Indonesia.

Nilai koefisien determinasi dari model summary diketahui bahwa, nilai $R$ square sebesar 0,163, artinya tata kelola pemerintah daerah (LnTKPD) hanya mampu menjelaskan $16,3 \%$ transparansi pengelolaan keuangan daerah. Hal ini mengindikasikan bahwa sebesar 83,7\% dijelaskan oleh variabel lain. Sementara nilai koefisien regresi tata kelola pemerintah daerah (LnTKPD) adalah sebesar 3,151. Variabel tata kelola pemerintah daerah mempunyai t hitung sebesar 2,413 dan nilai signifikansi sebesar 0,022. Nilai signifikansi tata kelola pemerintah daerah sebesar 0,022 lebih rendah dari taraf signifikansi yang ditetapkan yaitu sebesar $0,05(0,022<0,05)$, sehingga dapat diartikan 
bahwa tata kelola pemerintah daerah berpengaruh positif dan signifikan terhadap transparansi pengelolaan keuangan daerah. Lebih lanjut dapat dilihat pada Lampiran II penelitian ini.

Pembahasan. Pengaruh tata kelola pemerintah daerah terhadap transparansi pengelolaan keuangan daerah positif dan signifikan, yang berarti bahwa semakin berkualitas tata kelola pemerintah daerah menjadikan tingkat transparansi pengelolaan keuangan daerah yang semakin tinggi pula. Hasil ini menegaskan bahwa hipotesis alternatif yang diajukan dalam penelitian ini diterima. Temuan ini sejalan dengan hasil penelitian di sektor privat (perusahaan) (lihat, Beekes dan Brown, 2006; Arman et al., 2012; Beekes et al., 2014; 2016a; 2016b) yang menemukan bahwa tata kelola perusahaan menjadikan perusahaan lebih informatif (transparan).

Selanjutnya, temuan ini menguatkan argumen Ajinkya (2005) berdasarkan hasil penelitiannya di sektor privat (perusahaan) yang menyatakan bahwa mempromosikan tata kelola yang lebih kuat sama halnya dengan mempromosikan pengungkapan yang lebih transparan. Begitu pula, argumen Aman et al (2011) yang menyatakan keterlibatan yang lebih besar dari direksi eksternal (di luar managemen), dapat memfasilitasi pengawasan yang lebih efektif, sehingga mengarah pada pengungkapan yang lebih baik (Beekes dan Brown, 2006) dan informasi asimetri yang lebih rendah (Kanagaretnam et al, 2007). Dengan demikian, penerapan tata kelola yang berkualitas mampu menjadi penghambat aktivitas penyembunyian informasi, sehingga mengarah pada penyajian informasi yang seluas-luasnya demi peningkatan kesejahteraan bagi semua pihak.

Dalam konteks sektor publik (pemerintah), temuan penelitian ini mempertegas argumentasi Mardiasmo (2004) yang menjelaskan bahwa fungsi pengawasan yang dilakukan oleh legislatif dan partisipasi masyarakat secara langsung maupun tidak langsung melalui LSM dan organisasi sosial kemasyarakatan di daerah (social control) menjadi kekuatan penyeimbang (balance of power) bagi eksekutif daerah. Akhirnya, untuk meningkatkan kadar transparansi pengelolaan keuangan daerah di masa mendatang, sebagai salah satu solusinya adalah dengan memperbaiki kualitas tata kelola pemerintah daerah pada saat ini (masa sekarang).

Peningkatan kualitas tata kelola pemerintah daerah, disebut pula dengan tata kelola pemerintah daerah yang baik. Menurut IGI (2012) berawal dari bagaimana masyarakat (arena masyarakat sipil), pembuat kebijakan politik (arena pemerintah), pelaksana kebijakan (arena birokrasi), dan pelaku ekonomi (arena masyarakat ekonomi) bersinergi dalam membangun kehidupan yang baik (bebas, adil, aman, dan sejahtera). Lebih lanjut, tata kelola yang baik dicapai bila keempat arena di atas berinteraksi dalam suatu keseimbangan sehingga menciptakan suatu sinergi pembangunan yang memberikan hasil bagi kepentingan bersama. Mengingat, keempat arena tersebut memiliki fungsi dan kinerja yang secara simultan menentukan kualitas tata kelola di setiap pemerintah daerah, maka selaku pejabat publik berkewajiban untuk senantiasa menjaga simpul interaksi tersebut melalui regulasi maupun kebijakan.

\section{PENUTUP}

Simpulan. Penelitian ini bertujuan untuk menganalisis pengaruh tata kelola pemerintah daerah terhadap transparansi pengelolaan keuangan daerah. Penelitian ini dilakukan pada 32 pemerintah daerah di Indonesia. Penelitian ini menggunakan jeda waktu selama tiga 
tahun, yaitu data tata kelola pemerintah daerah tahun 2012 dihubungkan (diregresikan) dengan data transparansi pengelolaan keuangan daerah tahun 2016. Hasil regresi menunjukkan bahwa tata kelola pemerintah daerah berpengaruh positif terhadap transparansi pengelolaan keuangan daerah. Temuan penelitian ini sejalan dengan penelitian yang dilakukan oleh Beekes dan Brown (2006), Arman et al. (2012), Beekes et al. (2014; 2016a; 2016b) dalam konteks tata kelola perusahaan. Mereka menemukan bahwa kualitas tata kelola menjadikan pengungkapan lebih informatif (lebih transparan). Dengan demikian dapat dikatakan bahwa hasil yang sama, yang ditemukan dalam lingkungan perusahaan juga ditemukan dalam lingkungan pemerintahan di Indonesia.

Kontribusi Penelitian. Berdasarkan model regresi, penelitian ini menemukan bahwa variabel tata kelola pemerintah daerah memiliki pengaruh positif terhadap transparansi pengelolaan keuangan daerah. Dengan kata lain, temuan ini mengindikasikan bahwa peningkatan kualitas tata kelola pemerintah daerah berimplikasi pada peningkatan peringkat transparansi pengelolaan keuangan daerah. Temuan tersebut memiliki beberapa implikasi praktis sebagai berikut.

1) Bagi pejabat pemerintahan (Kemendagri), temuan ini dapat dijadikan tambahan informasi yang dapat dijadikan bukti baru dalam merumuskan, menyusun, dan menetapkan peraturan dan kebijakan yang efektif. Peraturan dan keputusan tersebut terkait dengan upaya peningkatan transparansi pengelolaan keuangan daerah di masa mendatang. Salah satunya adalah dengan memberikan perhatian yang lebih pada aspek tata kelola pemerintah daerah, apabila ingin meningkatkan kadar transparansi pengelolaan keuangan daerah di masa mendatang. Untuk itu, pejabat pemerintahan terkait perlu memberikan apresiasi berupa penghargaan (reward) bagi pemerintah daerah yang memperoleh nilai tata kelola tertinggi (terbaik), sebaliknya pemerintah daerah yang mendapatkan nilai tata kelola yang terendah (terburuk) diberikan pembinaan.

2) Bagi pemerintah daerah, temuan penelitian ini dapat dijadikan bahan evaluasi atas hasil pelaksanaan transparansi pengelolaan keuangan daerah. Dengan adanya informasi ini, pemerintah daerah dapat lebih tegas dalam menginstruksikan kepada jajarannya untuk selalu mempublikasikan informasi pengelolaan keuangan daerah atas aktivitas yang dilaksanakannya.

3) Bagi akademisi, temuan penelitian ini dapat dijadikan dasar bagi penelitian yang terkait dengan topik tata kelola pemerintah daerah dan transparansi pengelolaan keuangan daerah.

Keterbatasan dan Saran Untuk Penelitian Selanjutnya. Penelitian ini dilakukan di 32 pemerintah daerah sehingga memiliki keterbatasan generalisasi. Oleh karena itu, Penelitian selanjutnya dapat menguji kembali hasil penelitian ini dengan menggunakan sampel yang lebih banyak. Penelitian ini mengukur tata kelola pemerintah daerah dengan menggunakan nilai tata kelola daerah yang dikeluarkan Indonesia Governance Index tahun 2012, penelitian selanjutnya dapat menggunakan nilai tata kelola daerah terbaru. Selain itu, penelitian ini terbatas pada satu variabel independen saja dalam memprediksi variabel dependen. Penelitian selanjutnya dapat menambahkan variabel independen, seperti kemampuan keuangan (financial independence), solvabilitas keuangan, indeks pendidikan masyarakat, ukuran (size), dan umur pemerintah daerah. 


\section{DAFTAR RUJUKAN}

Abdillah, W. dan J.Hartono. (2015) Partial Least Square (PLS): alternatif structural equation modeling (SEM) dalam penelitian bisnis. Andi: Yogyakarta.

Ajinkya, B., S.Bhoraj, and P. Sengupta. (2005) 'The governance role of institutional investors and outside directors on the properties of management earnings forecasts'. Journal of Accounting Research, 43 (3).

Aman, H., W.Beekes, and P. Brown. (2011) "Corporate governance and transparency in Japan". Working Paper (Universities of Kwansei Gakuin, Lancaster, New South Wales and Western Australia).

Beekes, W. and Brown P. (2006) "Do better-governed australian firms make more informative disclosures?”. Journal of Business Finance \& Accounting, 33(3) \& (4), 422-50.

Beekes, W., Brown P. and Q. Zhang. (2014) Corporate Governance and the Informativeness of Disclosures in Australia: A Re-examination. Accounting and Finance, 55(4), 931-63.

Beekes, W., P.Brown, G.Chin, andQ. Zhang. (2016a) "Corporate governance, companies' disclosure practices and market transparency: a cross country study". Journal of Business Finance \& Accounting, 43 (3) \& (4), 263-297.

Beekes, W., P.Brown, G.Chin, and Q. Zhang. (2016b) "The effects of corporate governance on information disclosure, timeliness and market participants' expectations". Accounting and Finance Association of Australia and New Zealand conference.

Birkinshaw, M. M. J. (2006) "How management innovation happens". MIT Sloan management review, 47(4), 81.

Badan Perencanaan Pembangunan Nasional. (2014) Rancangan awal: rencana pembangunan jangka menengah nasional 2015-2019. Jakarta.

Chalid, P. (2005) Keuangan daerah investasi, dan desentralisasi: tantangan dan hambatan. Kemitraan untuk tata kelola pemerintahan yang baik: Jakarta.

Danayanti, M. (2014) “Analisis pengaruh pendapatan asli daerah (pad), dana alokasi khusus (dak) dan selisih perhitungan anggaran (silpa) terhadap realisasi belanja modal dan pertumbuhan ekonomi”. Tesis Universitas Gadjah Mada. Tidak terpublikasi.

Ghozali, I. (2011) Aplikasi analisis multivariate dengan program IBM SPSS 19. Badan Penerbit Universitas Diponegoro: Semarang.

Hartono, J. (2011) Metode penelitian bisnis: salah kaprah dan pengalaman-pengalaman. BPFE UGM: Yogyakarata.

Hart, O. (1995) "Corporate governance: Some theory and implication". The Economic Journal, 105 (430), 678-89.

Hermalin, B. E. and M. S.Weisbach. (2012) "Information Disclosure and Corporate Governance". The Journal of Finance, 67 (1), 195-233.

Hermana, B., A.Taringan, H. Medyawati, dan W. Silfianti. (2012) "E-Government Implementation in Indonesia: Financial Transparency on the Web, 3rd". International Conference on e-Education, e-Business, e-Management and $e$ Learning IPEDR, 27, 194-199. 
Hirsch, W. Z., and E. Osborne. (2000) "Privatization of government services: Pressuregroup resistance and service transparency". Journal of Labor Research, 21(2), 315326.

Humayun, Md., K and I. Adelopo. (2012) "Corporate governance disclosure practices by Swaziland public enterprises". African Journal of Business Management, 6(24), $7136-7148$.

Huwae, K. (2016) "Analisis tingkat keterbukaan informasi pengelolaan keuangan daerah (Studi di Provinsi Daerah Istimewa Yogyakarta)". Tesis Universitas Gadjah Mada. Tidak terpublikasi.

Instruksi Mendagri Nomor 188. 52/1797/SC/2012 tentang Transparansi Pengelolaan Anggaran Daerah (TPAD).

Instruksi Presiden Republik Indonesia Nomor 7 Tahun 2005 tentang Aksi Pencegahan dan Pemberantasan Korupsi Tahun 2015.

Indonesia Governance Index (IGI). (2012) Menuju masyarakat yang cerdas dan pemerintah yang responsif: laporan eksekutif Indonesia Governance Index 2012. http: //kemitraan.or.id/igi/documents/data/Laporan\%20 Eksekutif\%20IGI.pdf.

Jensen MC and WH. Meckling. (1976) "Theory of the firm: Managerial behaviour, agency costs and ownership structure". J. Financ. Econ., 3(4), 305-360.

Mardiasmo. (2009) Akuntansi sektor publik. Yogyakarta: Penerbit Andi.

Mardiasmo. (2004) Otonomi dan manajemen keuangan daerah. Yogyakarta: Penerbit Andi.

Martani, D. Fitriasari, D. \& Annisa. (2014) "Financial and Performance Transparency on The Local Government Websites in Indonesia". Journal of Theoretical and Applied Information Technology. 60, 504-518.

Marvin, Henry. (2012) "Evaluasi penyusunan indikator kinerja pada pemerintah kabupaten bantul”. Tesis. Maksi UGM Yogyakarta, tidak dipublikasikan.

Peraturan Pemerintah No. 71 Tahun 2010 tentang Standar Akuntansi Pemerintahan (SAP)

Peraturan Menteri Dalam Negeri Nomor 13 tahun 2006 Tentang Pedoman Pengelolaan Keuangan Daerah.

Peraturan Pemerintah Nomor 58 tahun 2005 tentang pengelolaan keuangan daerah.

Sekretariat Nasional Forum Indonesia untuk Transparansi Anggaran (SEKNAS FITRA). (2013) Indeks keterbukaan badan publik menyediakan informasi anggaran secara berkala: mengukur keterbukaan informasi anggaran berbasis website.sekretariat@seknasfitra.org/www.seknasfitra.org.

Shopia, A. dan Husen, B. (2013) "Analisis transparansi dan akuntabilitas pemerintah daerah melalui pengungkapan informasi pada website (studi pada kota/kabupaten seluruh Indonesia)". Jurnal Media Indonesia, 12 (4).

Spanhove, J.,and K. Verhoest. (2007) Corporate governance vs. government governance: translation or adaptation?. Paper for the eiasm 4th workshop on corporate governance brussels.

Tsamenyi M., E.Enninful-Adu, and J.Onumah. (2007) "Disclosure and corporate governance in developing countries: evidence from Ghana". Manag. Audit. J., 22(3), 319-334.

Undang-Undang Nomor 32 tahun 2004 tentang Pemerintahan Daerah

Undang-Undang Nomor 17 tahun 2003 tentang Keuangan Negara 
Undang-Undang Nomor 33 tahun 2004 tentang Perimbangan Keuangan Antara Pusat dan Pemerintah Daerah

Undang-Undang Nomor 14 tahun 2008 tentang Keterbukaan Informasi Publik

Undang-Undang Nomor 15 Tahun 2005 tentang Pemeriksaan Pengelolaan dan Tanggung Jawab Keuangan Negara 
LAMPIRAN-LAMPIRAN:

Lampiran I: Rincian Indikator Tahapan Pengelolaan Keuangan Daerah

\begin{tabular}{|c|c|c|}
\hline Tahapan & Rincian Indikator & Tahun \\
\hline \multirow{10}{*}{ Perencanaan } & Ringkasan Dokumen RKPD & 2016 \\
\hline & Kebijakan Umum Anggaran & 2016 \\
\hline & Ringkasan Dokumen Prioritas dan Plafon Anggaran & 2016 \\
\hline & Ringkasan Dokumen RKA-SKPD & 2016 \\
\hline & Ringkasan Dokumen RKA-PPKD & 2016 \\
\hline & $\begin{array}{c}\text { Ringkasan Dokumen Rancangan Peraturan Daerah } \\
\text { tentang APBD }\end{array}$ & 2016 \\
\hline & Peraturan Daerah tentang APBD & 2016 \\
\hline & Peraturan Kepala Daerah tentang Penjabaran APBD & 2016 \\
\hline & Ringkasan DPA SKPD & 2016 \\
\hline & DPA PPKD & 2016 \\
\hline \multirow{9}{*}{ Pelaksanaan } & Realisasi Pendapatan Daerah & 2016 \\
\hline & Realisasi Belanja Daerah & 2016 \\
\hline & Realisasi Pembiayaan Daerah & 2016 \\
\hline & Ringkasan Dokumen Rancangan Perubahan APBD & 2016 \\
\hline & Peraturan Daerah tentang Perubahan APBD & 2016 \\
\hline & $\begin{array}{l}\text { Peraturan Kepala Daerah tentang Penjabaran Perubahan } \\
\text { APBD }\end{array}$ & 2016 \\
\hline & Ringkasan RKA Perubahan APBD & 2016 \\
\hline & Rencana Umum Pengadaan & 2016 \\
\hline & $\begin{array}{c}\text { SK Kepala Daerah tentang Pejabat Pengelola Keuangan } \\
\text { Daerah }\end{array}$ & 2016 \\
\hline \multirow{10}{*}{$\begin{array}{c}\text { Pelaporan dan } \\
\text { Pertanggungjawaban }\end{array}$} & Peraturan Kepala Daerah tentang Kebijakan Akuntansi & 2016 \\
\hline & Laporan Arus Kas & 2015 \\
\hline & Laporan Realisasi Anggaran Seluruh SKPD & 2015 \\
\hline & Laporan Realisasi Anggaran PPKD & 2015 \\
\hline & Neraca & 2015 \\
\hline & CaLK Pemerintah Daerah & 2015 \\
\hline & Laporan Keuangan BUMD/Perusahaan Daerah & 2015 \\
\hline & $\begin{array}{c}\text { Laporan Akuntabilitas dan Kinerja Tahunan Pemerintah } \\
\text { Daerah }\end{array}$ & 2015 \\
\hline & $\begin{array}{l}\text { Penetapan Perda Pertanggungjawaban Pelaksanaan } \\
\text { APBD }\end{array}$ & 2015 \\
\hline & Opini BPK RI & 2015 \\
\hline
\end{tabular}

Instrumen: Diadaptasi dari penelitian Huwae (2016) 
Syamsul dan Ritonga: Pengaruh Tata Kelola Pemerintah Daerah Terhadap Transparansi...

\section{Lampiran II: Output SPSS IBM 21}

1.

Statistik Deskriptif

Descriptive Statistics

\begin{tabular}{|l|r|r|r|r|r|}
\hline & \multicolumn{1}{|c|}{$\mathrm{N}$} & Minimum & Maximum & \multicolumn{1}{c|}{ Mean } & Std. Deviation \\
\hline TKPD & 32 & 4,45 & 6,80 & 5,7378 &, 54490 \\
TPKD & 32 & 3,45 & 50,00 & 17,2419 & 13,14526 \\
Valid N (listwise) & 32 & & & & \\
\hline
\end{tabular}

2.

Analisis Regresi Sederhana

Model Summaryb

\begin{tabular}{|l|r|r|r|r|}
\hline Model & $\mathrm{R}$ & $\mathrm{R}$ Square & $\begin{array}{c}\text { Adjusted R } \\
\text { Square }\end{array}$ & $\begin{array}{c}\text { Std. Error of the } \\
\text { Estimate }\end{array}$ \\
\hline 1 &, $403^{\mathrm{a}}$ &, 163 &, 135 &, 71649 \\
\hline
\end{tabular}

a. Predictors: (Constant), LnTKPD

b. Dependent Variable: LnTPKD

ANOVA $^{a}$

\begin{tabular}{|rl|r|r|r|r|r|}
\hline \multicolumn{1}{|l|}{ Model } & Sum of Squares & df & Mean Square & F & Sig. \\
\hline \multirow{2}{*}{1} & Regression & 2,989 & 1 & 2,989 & 5,822 &, $022^{\mathrm{b}}$ \\
& Residual & 15,401 & 30 &, 513 & & \\
& Total & 18,390 & 31 & & & \\
\hline
\end{tabular}

a. Dependent Variable: LnTPKD

b. Predictors: (Constant), LnTKPD

Coefficients $^{a}$

\begin{tabular}{|c|c|c|c|c|c|c|}
\hline \multirow[t]{2}{*}{ Model } & & \multicolumn{2}{|c|}{ Unstandardized Coefficients } & \multirow{2}{*}{$\begin{array}{c}\text { Standardized } \\
\text { Coefficients }\end{array}$} & \multirow[t]{2}{*}{$\mathrm{t}$} & \multirow[t]{2}{*}{ Sig. } \\
\hline & & $B$ & Std. Error & & & \\
\hline & (Constant) & $-2,919$ & 2,279 & & $-1,281$ & ,210 \\
\hline & LnTKPD & 3,151 & 1,306 & ,403 & 2,413 & 022 \\
\hline
\end{tabular}

a. Dependent Variable: LnTPKD

3.

Uji Normalitas

Coefficients $^{a}$

\begin{tabular}{|c|c|c|c|c|c|c|}
\hline \multirow[t]{2}{*}{ Model } & & \multicolumn{2}{|c|}{ Unstandardized Coefficients } & \multirow{2}{*}{$\begin{array}{c}\begin{array}{c}\text { Standardized } \\
\text { Coefficients }\end{array} \\
\text { Beta }\end{array}$} & \multirow[t]{2}{*}{$\mathrm{t}$} & \multirow[t]{2}{*}{ Sig. } \\
\hline & & $B$ & Std. Error & & & \\
\hline & (Constant) &, 559 & ,783 & & ,714 & ,481 \\
\hline & TKPD & ,002 & ,136 & ,002 & 011 & ,991 \\
\hline
\end{tabular}

a. Dependent Variable: ABSUnres

One-Sample Kolmogorov-Smirnov Test

\begin{tabular}{|ll|r|}
\hline & & $\begin{array}{r}\text { Unstandardized } \\
\text { Residual }\end{array}$ \\
\hline Normal Parameters & Mean & Mean \\
& Std. Deviation &, 0000000 \\
Most Extreme Differences & Absolute &, 70483558 \\
& Positive &, 080 \\
Kolmogorov-Smirnov Z & Negative &, 080 \\
Asymp. Sig. (2-tailed) & &,- 063 \\
\hline
\end{tabular}

a. Test distribution is Normal. 
Syamsul dan Ritonga: Pengaruh Tata Kelola Pemerintah Daerah Terhadap Transparansi...

Normal P-P Plot of Regression Standardized Residual Dependent Variable: LnTPKD

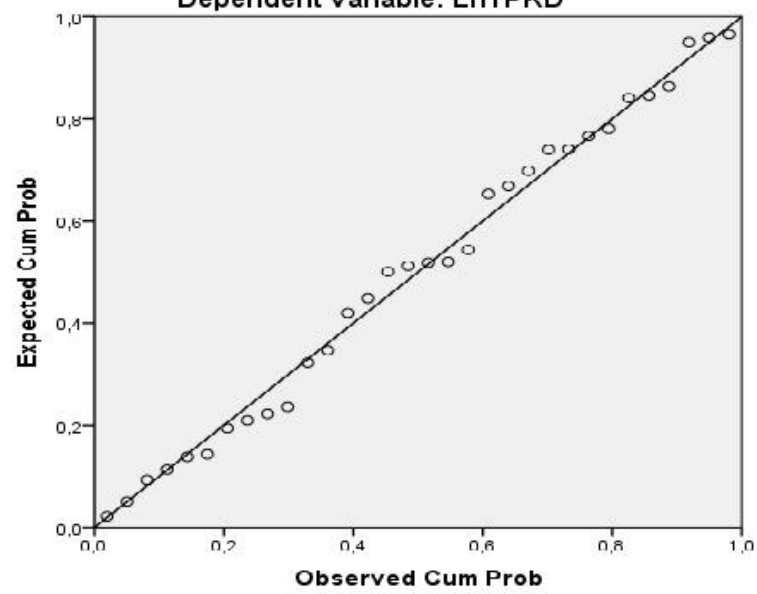

4.

Uji Heteroskedastisitas

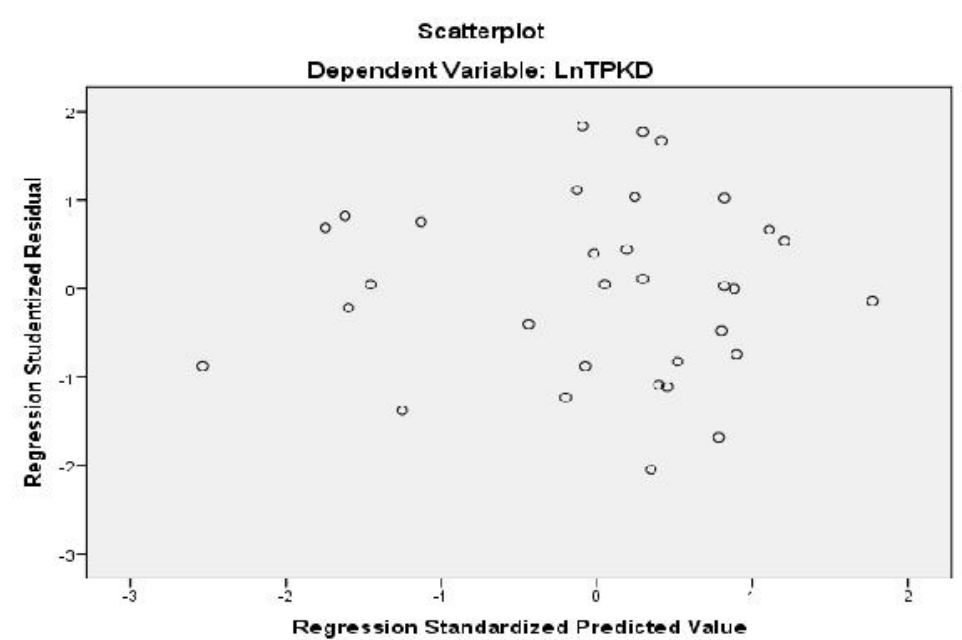

Coefficients $^{a}$

\begin{tabular}{|c|c|c|c|c|c|c|}
\hline \multirow[t]{2}{*}{ Model } & & \multicolumn{2}{|c|}{ Unstandardized Coefficients } & \multirow{2}{*}{$\begin{array}{c}\begin{array}{c}\text { Standardized } \\
\text { Coefficients }\end{array} \\
\text { Beta } \\
\end{array}$} & \multirow[t]{2}{*}{$\mathrm{t}$} & \multirow[t]{2}{*}{ Sig. } \\
\hline & & $B$ & Std. Error & & & \\
\hline \multirow{2}{*}{1} & (Constant) & ,559 & ,783 & & ,714 & ,481 \\
\hline & TKPD & ,002 & , 136 & ,002 & 011 & ,991 \\
\hline
\end{tabular}

a. Dependent Variable: ABSUnres

Correlations

\begin{tabular}{|ll|r|r|r|}
\hline & & LnTKPD & LnTPKD & ABSUnres \\
\hline \multirow{3}{*}{ LnTKPD } & Pearson Correlation & 1 &, $403^{*}$ &, 019 \\
& Sig. (2-tailed) & &, 022 &, 918 \\
& $\mathrm{~N}$ & 32 & 32 & 32 \\
& Pearson Correlation &, $403^{*}$ & 1 &,- 011 \\
LnTPKD & Sig. (2-tailed) &, 022 & &, 950 \\
& $\mathrm{~N}$ & 32 & 32 & 32 \\
& Pearson Correlation &, 019 &,- 011 & 1 \\
ABSUnres & Sig. (2-tailed) &, 918 &, 950 & \\
& $\mathrm{~N}$ & 32 & 32 & 32 \\
\hline
\end{tabular}

*. Correlation is significant at the 0.05 level (2-tailed). 